Fabrizio Macagno*

\title{
A dialectical approach to presupposition
}

https://doi.org/10.1515/ip-2018-0008

\begin{abstract}
This paper advances an approach to presupposition rooted in the concept of commitment, a dialectical notion weaker than truth and belief. It investigates ancient medieval dialectical theories and develops the insights thereof for analyzing how presuppositions are evaluated and why a proposition is presupposed. In particular, at a pragmatic level, presuppositions are reconstructed as the conclusions of implicit arguments from presumptive reasoning, grounded on presumptions of different type and nature. A false (or rather unaccepted) presupposition can be thus represented as the outcome of a conflict of presumptions - the ones used by the speaker and the ones commonly accepted or backed by evidence. From an interpretative perspective, this defaulted presumptive reasoning can be explained by comparing the available presumptions and repaired by replacing the weaker and unacceptable ones.
\end{abstract}

Keywords: presupposition, argumentation schemes, pragmatics, presumptions, commitment

\section{Introduction}

The phenomenon of presupposition is one of the most debated issues in philosophy of language. It is normally related to puzzles concerning the cancellation, suspension, or neutralization of presuppositions (Capone 2017), or the truthvalue of statements with false presuppositions, such as the famous, "The king of France is bald." In the modern philosophical tradition, such puzzles have been investigated starting from the works of Frege (Frege 1948), Russell (Russell 1905), and Strawson (Strawson 1964). This theoretical debate, however, is only apparently recent. The history of presuppositional puzzles goes back to ancient dialectical dilemmas, such as the horned man paradox (Seuren 2005), which were addressed in many medieval works that constituted the backbone of ancient dialectics. The goal of this paper is bring to light the traditional analysis of presupposition, and build on the ancient distinctions to propose a dialectical approach to this problem, where "dialectical" refers to the traditional art of

*Corresponding author: Fabrizio Macagno, IFILNOVA, FCSH NOVA, Lisbon, Portugal, E-mail: fabrizio.macagno@fcsh.unl.pt 
reasoning in discourse currently revived in contemporary argumentation theories(Walton 2006; Toulmin 1958; Kienpointner 1992, 2001).

This dialectical (argumentative) approach can provide a different perspective within the philosophical discussions concerning presupposition. In particular, it is claimed that presuppositions can be investigated in terms of commitments, namely a type of socially bind relation (Seuren 2009:140) (dialectical obligation) resulting from the explicit or implicit acceptance of a proposition. Moreover, this account can help explain how a presupposition affects the commitments of the hearer, and how the latter can deny an unaccepted presupposition. It can provide a possible representation of the reasoning mechanism underlying a presupposition, namely its presumptive effect. Finally, it can advance a theoretical explanation of presuppositional failures, and predict operationally how they can be assessed, accounted for, and repaired in terms of presumptions.

\section{Presuppositions in dialectics}

The medieval logicians addressed dilemmas of presupposition somehow similar to the ones currently debated in philosophy. The ancient solutions to these problems can provide new insights and distinctions that can be combined with the modern advances, and suggest a dialectical, commitment-based approach to presupposition.

\subsection{Presuppositional puzzles in the dialectical tradition}

In the medieval tradition, philosophers struggled with two crucial presuppositional problems, some presuppositional triggers belonging to the category of syncategorematic words (for example "only" or "to stop") and the negation of propositions with subjects referring to non-existent entities ("the chimaera is flying”) (Seuren 2010:chap. 10).

Coherent with the Aristotelian two-valued logic, medieval logicians did not postulate the possibility of the lack of a truth-value (Seuren 2005). In contrast, the syncategorematic presupposition triggers were studied as a conjunction of propositions. For example, in Abelard (Abaelardus, Dialectica, 332) and William of Sherwood (William of Sherwood, Treatise on Syncategorematic words, 12, 15), sentences such as “Only Socrates runs" are analyzed as constituted of two propositions, one positive (Socrates runs) and the other negative (no one else runs).The relationship between the exclusive proposition and the one underlying the excluding adverb (preiacens) was set out by Peter of Spain as follows 
(Horn 2011:199): “every true exclusive proposition leaves the truth of the basic proposition intact” (Petrus Hispanus Syncategoreumata, III, 10). This relation cannot be considered as a presuppositional relation (contra Horn 1996: 300; see Seuren 2005), since it concerns the double meaning of an exclusive proposition, from which it is possible to infer the truth of two propositions that are logically at the same level (they are both "included" in the original proposition) (Petrus Hispanus Syncategoreumata, III, 22).

The problem of propositions with non-existent referents was addressed by considering the possible inferences that can be drawn from them, and the different types of negation. The inference from the attribution of a predicate to a subject to the existence of the referent thereof (Ashworth 1973) was regarded by Abelard as material or imperfect, namely depending on the nature of the predicate (MacFarlane 2015). This account can explain some sophisms commonly addressed in the Middle Ages, such as the following (Petrus Hispanus Summulae Logicales, VIII, 122; Abaelardus Dialectica, 137):

A chimera is a matter of opinion (est opinabile)

Therefore there is a chimera

The inference in this case does not hold because the predicate ("to be matter of opinion") does not "contain" the existence of the subject (De Libera 2011:466; Seuren 2010:364-365).

On Abelard's view, a proposition can be negated in two fashions: by means of an extinctive negation ("it is false that the chimaera is flying," later called "total removal" by Thomas Aquinas, in Expositio libri Peryermeneias, I, 10, 18) or through a separative negation ("the chimaera is not flying") (Martin 2012; Martin 2004). However, Abelard pointed out that while in case of a separative negation the subject is taken as existent, an extinctive negation does not lead to inferring either its existence or its non-existence (Abaelardus Dialectica,177). In case of the chimaera, the proposition is "very false" as the chimera does not exist (Ashworth 1973).

The term "praesuppositio" was introduced by Thomas Aquinas in the thirteenth century to refer to a specific epistemic and dialectical attitude towards a proposition, namely the previous acceptance of a proposition (Aquinas In Libros Metaphysicorum Expositio, VII, 17, 19). In this sense, a presupposition is close to the concept of pragmatic presupposition (Stalnaker 1974; Simons 2003; Capone 2017). According to Aquinas, the possibility of asking a question depends on the knowledge (and more precisely the interlocutor's knowledge) of the presupposed proposition. Aquinas used the term "praesuppositio" also in an absolute sense to refer to a condition of the order of reason (Rhonheimer 2000), and more precisely to a semantic implication from a predicate (e. g. "to be red") to a precondition of the 
predication (e. g. "to be a surface"). This relation results from the "essence" (namely the definition) of the predicate (McCabe 1969:65-69), which establishes a rule of predication consisting in the previous acceptance of its precondition (Summa Theologiae, 1a, 76, a3). According to Aquinas, "presupposition" is characterized by its definitional nature and its logical anteriority, or precedence in the "order of intelligence" (Summa Theologiae, 2a2ae, a14). By pointing out that one property logically precedes (or presupposes) another, Aquinas infers that, if we grant the latter, we must admit the former. In this sense, logical presuppositions are preconditions or rules of the language game and are taken as accepted by the interlocutors (McCabe 1969:68).

These presuppositional puzzles were investigated in the Middles Ages using a twofold approach to verification. A proposition was verified either absolutely, at a "metaphysical" level (through a comparison with an objective state of affairs), or dialectically, by assessing the consistency of a sentence with the set of sentences previously agreed upon by the participants to a dialogue, nowadays called "commitments." Such agreed upon sentences constitute the interlocutors' “obligations” (Martin 2001; Uckelman 2013; Novaes Dutilh 2007: chap. 3), limiting the interlocutors' freedom to contradict or deny them. On the dialectical (commitment-based) account of verification, a sentence needs to be assessed considering the commitment set of the participant that is evaluating it. A presupposition is thus evaluated considering what the participant holds as true; if the hearer is committed to the truth of sentences contradictory or incompatible with it, s/he will classify it as false. Otherwise, the hearer can hold it as true or as provisionally true (Schlenker 2008:169).

\subsection{A dialectical approach to presupposition}

In the ancient approaches to presupposition, we can identify three interrelated problems, which result from three distinct levels of analysis:

1. At a dialectical (pragmatic) level, a presupposition consists in taking for granted the interlocutor's knowledge of a proposition on which the felicity of a speech act depends (as Aquinas put it, nothing is asked when the presupposition of a question is not known by the hearer).

2. At a logical-semantic level, presuppositions are the conditions of predication, namely the requirements that need to be fulfilled for a predicate to be correctly used. Presuppositions are thus semantic preconditions that depend on the definition of the predicate used. Presuppositional failure results in illformed sentences, characterized by the ungrammatical use of a predicate. 
3. At a logical level (in which no interlocutor nor any prior knowledge is taken into consideration), presuppositions are regarded as inferences that are triggered by the logical subject of a predication, and thus result from both the affirmation and the separative negation of a proposition. The falsity of a presupposition results in the falsity of the proposition from which it is inferred. However, the denial of a presupposition results in a stronger denial of the presupposing proposition, as the opposition between the affirmation of a proposition and its extinctive negation (denying also the presupposition) is stronger than a simple separative negation (Seuren 2010:361).

These distinctions can be used to interpret the contemporary discussions on semantic and pragmatic presupposition (Huang 2014:chap. 3), in particular drawing a distinction between the logical and the pragmatic level, and the metaphysical and dialectical account of verification.

From a dialectical perspective, at a logical level a presupposition can be considered as logically implied by the use of a sentence; it is "a distinguished part of a bivalent meaning, one that strives to be articulated as a separate conjunct" (Schlenker 2008:160). In particular, the topical component in the information structure, which is pragmatically given and thus dialectically taken as accepted (Gundel and Fretheim 2004:177; Strawson 1971; Atlas 1991, 2004; Beaver 2010), can be logically articulated as a separate conjunct, together with the asserted component (focus) ( $p$ and $p p$ ). The asserted component, however, is true only if the presupposed content is true. Thus, at a logical level the falsity of a presupposition - such as the falsity of the presupposition in "The king of France is bald" - ( Schlenker 2008, 181) has three effects:

1. It implies the falsity of the second conjunct (the king of France is bald only if the king of France exists);

2. It implies the falsity of the conjunction (It is false that the king of France exist and that the king of France is bald);

3. No further inferences can be drawn concerning the condition of the head of the king (such as "the king of France is less attractive").

4. Possible inferences can be drawn from the falsity of the first conjunct (for example, "France is not a monarchy").

According to this view, to evaluate a sentence carrying a presupposition, we need to distinguish between two crucial cases:

a. The presupposition can be assessed as true or false Ex: The king of France is bald ( $p p$ : there is a king of France).

b. The presupposition cannot be assessed as true or false (the referent of the subject term cannot be identified). 
Ex: Bob was at the party ( $p p$ : there is someone called Bob that the hearer can identify) (uttered to an interlocutor who does not know who Bob is).

In the first case, the presupposition can be reconstructed by the hearer as an "implicit content" of the sentence token (Bach 1999). Since the presupposition can be determined and evaluated as false, the sentence is a fortiori false (or "very false"). In the second case, the hearer cannot reconstruct the presupposition, as s/he does not know any Bob (Asher and Lascarides 1998:255). For this reason, reference failure results in the impossibility of assessing the presupposition (Gazdar 1979; Hobbs 1979; Simons 2003; von Fintel 2008; Atlas 2008; Lewis 1979), and thus the sentence itself is a spurious (or improper) sentence (Clark and Brennan 1991:226), to which the criterion of verifiability does not apply and which cannot result in a commitment. In this case, the hearer cannot even reconstruct the proposition expressed (Macagno 2015; Macagno and Walton 2014:chap. 4). On this perspective, the possibility of reconstructing the presupposed content is distinguished from its assessment.

The dialectical analysis of presuppositions allows drawing distinctions at the level in which presuppositions are analyzed. At a logical level, presuppositions are regarded as sentences that are evaluated against a set of pre-existing commitments and that can be accepted either as true or false. A presupposition cannot be evaluated for two reasons: either because it is incomplete (and, therefore, it is not a proposition), or because it cannot be verified considering the hearer's commitment store (the hearer does not know whether it is true or false). In the first case, the sentence itself is spurious. In the second case, the hearer can evaluate it provisionally as true or false depending on the coherence thereof with his commitment store, and later on he can still evaluate it differently depending on the further modifications of his commitments.

This account, however, leads to further questions concerning the pragmatic level, and more specifically, concerning the relationship between presuppositions and commitments and the dialectical effects of presuppositions.

\section{Commitments and presumptive reasoning}

At a pragmatic level, presuppositions are analyzed in the literature in terms of common ground, considering the relationship between "a person and a proposition" (Stalnaker 1973:447). Thus, presuppositions can be regarded as propositions that the speaker treats as taken for granted, namely already accepted. From a dialectical perspective, two problems arise at this level, namely the relationship 
between presuppositions and common ground, and the conditions of the previous acceptance (vis-à-vis the asserted component) of the presupposed content.

\subsection{Presuppositions, common ground, and commitments}

The notion of "common ground" as commonly used in pragmatics (Clark and Brennan 1991; 222; Kecskes and Zhang 2009; see the distinc approach in Stalnaker 1984) is rooted in the interlocutors' beliefs or knowledge, which can hardly explain many cases of presuppositions that cannot be considered part of the hearer's beliefs or knowledge (Atlas 2005:144).

In dialectics, the propositions accepted by a participant to a dialogue are represented as commitments, which can be light-side (propositions explicitly accepted in the dialogue) or dark-side (propositions proved or presumed to be accepted by the hearer) (Walton and Krabbe 1995:124-126). Any speech act can be thus represented as a proposal of updating the interlocutors' commitment store (Ginzburg 1994; Ginzburg 1996; Walton and Krabbe 1995:23-24), which can be either accepted or refused.

Commitments are social responsibilties, dialogical obligations (Hamblin 1970:257) not correponding to beliefs (Ducrot 1984:79; Beyssade and Marandin 2009). They represent an interlocutor's acceptance of a proposition, namely treating it as true or at least ignoring the possibility that it is false (Stalnaker 1984:79). One accepts a statement when it is asserted and, in many contexts, when it is not objected or challenged (Mackenzie and Staines 1999:17; Hamblin 1970:264; Geurts 2017). It is possible to explain why a person commits himself to a proposition by making hypotheses about his beliefs ( $S$ commits to $p$ because $S$ believes that $p$ is true); however, this is only one of the possible explanations of his dialectical behavior. From a dialectical perspective, utterances are regarded considering the socially binding relation that they create (Seuren 2009:140), and not the intentions and beliefs of the interlocutors.

\subsection{Presuppositions, dialectical order, and commitment stores}

The notion of commitment characterizes the dialectical approach to communication (Hamblin 1970; Beyssade and Marandin 2009, 2006). On this perspective, presuppositions are analyzed as implicit commitments of the hearer (Geurts 1999: 4, 2017; Macagno 2012a, 2015; Macagno and Walton 2014:chap. 5). When a speaker presupposes some information, s/he is engaging in a specific game characterized by presumptions (Thomason 1990:337-338), characterizing both 
the interpretive process of the hearer and the interpretable activity of the speaker (Simons 2007; Levinson 2000:chap. 2). Not only does the speaker act based on the presumption of cooperativity of the hearer; the hearer is also the subject of presumptions needed for the hearer's interpretive activity (what Levinson refers to as the Recipient's Corollary of the Speaker's maxims). Thus, a speaker can use a presupposition because it can be presumed that securing the hearer's acceptance of the presupposed contents would be dialectically useless or redundant (and in conflict with the pragmatic principle of brevity).

When a speaker presupposes a proposition, he or she acts on and generates the presumption that there are reasons for considering the presupposition as part of the "dark-side" commitment store of the interlocutor. In this sense, presuppositions are intimately related to the speaker's reasons for presupposing, which is the condition for the hearer's interpretation (Macagno 2015, 2012a). For example, the interpretation of the assertion "Bob was at the party" is grounded on the basic presumption that the speaker has reasons for considering "Bob" and "the (specific) party (occurred at a specific time in the past)" as part of the hearer's commitments. This presumption will be the hearer's starting point for retrieving the dark-side commitments, i. e. for finding among the implicit commitments the individual "Bob" may refer to, and the event that "the party" individuates.

The speaker can also presuppose a proposition that was not previously accepted nor somehow part of the hearer's "dark-side" commitments, disrupting the dialectical order (Thomason 1990). However, communication is often based on unaccepted commitments that the hearer "accommodates" provisionally (Brennan and Clark 1996:1484). Sometimes this strategy is used for informative purposes (Ducrot 1968), such as in the case given above:

Bob was at the party (stated on the headline of a newspaper).

In the context of a newspaper article, the presupposed information (there is someone important called Bob the journalist is referring to) can be easily accommodated. The hearer can accept provisionally the commitment, waiting for further information on the identity of the individual. Informative presuppositions are also used for modifying the dialectical game, leaving up to the interlocutor the decision to inquire further into the presupposed but unshared information. A famous example is the following sentence told by a daughter to her father, who ignores that she has a boyfriend:

I will be moving to my boyfriend's place.

The father can reconstruct the presupposition and decide whether to accept it, or accept it provisionally, investigating the issue by starting a meta-dialogue or 
waiting for further information. The disruption of the dialectical order can be also only tentative. For example, the question of a bartender,

What are you having?

can be asked without securing the client's intention to have something to drink (Capone 2017; Macagno and Capone 2016). Here, the client can accept the presupposition or reject it. However, depending on the specific context (a restaurant or a café or pub), the rejection may be easier or more complex, depending on the grounds that the waiter has for presupposing the client's intention (in restaurants clients may want to drink something different from water; in pubs or cafés, by sitting down the client implicitly agrees to have a drink). For this reason, the analysis of the presupposition conditions needs to be focused on the reasons that the speaker has for holding a proposition as part of the interlocutor's commitment store.

\subsection{The conditions for presupposing}

The first and most basic condition consists in the possibility of accessing (identifying) the presupposed information, namely the hearer needs to be able to reconstruct the content taken for granted and connect it with his knowledge or the context (Asher and Lascarides 1998:277; Gazdar 1979; Hobbs 1979). In other words, the hearer needs to be able to retrieve or at least accommodate the presupposition (Simons 2003; von Fintel 2008; Atlas 2008; Lewis 1979). This condition is not enough, as the following possible scenarios result from it.

The presupposition $p p$ is reconstructed and

i) $\quad p p$ can be accepted by the hearer as a background assumption;

ii) $\quad p p$ can be accepted by the hearer as a background assumption provisionally (waiting for further information);

iii) $p p$ cannot be accepted by the hearer as it conflicts with other commitments;

iv) $\quad p p$ cannot be accepted by the hearer as the hearer cannot be presumed to accept $p p$.

In order to explain such cases, we can provide variants of the examples mentioned above in the paper:

i) a) "What are you having for a drink?" (asked by a waiter to a customer in a pub). b) "What are you having for a drink?" (asked by a waiter to a customer in a restaurant). c) "Bob was at Tom's party as well” (said to a 
teenager friend) (the hearer does not know that there was a party, but in the group of friends Tom is known to organize parties frequently).

ii) a) "Bob was at the party" (read on a newspaper headline) (the hearer does not know who Bob is, but accepts that there is someone important with this name). b) "I will be moving to my boyfriend's place" (told by the daughter to her father, who was not aware of the existence of a boyfriend).

iii) a) "Bob was at Tom's party as well" (said by a kid to Bob's mother) (the mother knows that Tom did not throw any party, and cannot accept it). b) "What beer are you having?" (asked by a friend) (the hearer knows that the restaurant does not serve alcohol).

iv) a) "Bob was at the party as well" (said to a stranger) (the hearer may be not presumed to know Bob or the party). b) "What meat dish are you having?" (asked by the waiter of a vegetarian restaurant to his customers).

The cases iii) and iv) are only apparently similar. They are similar because their effects can fall within the dialectical category of dialectically inappropriate statements (subject to the ancient accusation "nugaris"). In both cases, the speaker inserts into the hearer's commitments a proposition without ensuring that it has been accepted by the hearer himself (Stalnaker 2008:542). From the hearer's perspective the presupposition does not alter his or her commitments unless s/he accepts the move (Schlenker 2008:161-162). For this reason, s/he can deny it with an extinctive negation, such as in cases iii): "Bob was not at the party for sure!"; "I do not think I can have any beer here, I suppose.” Otherwise, hearer can refuse the move at a meta-dialogical level, namely pointing out that the assertion is inappropriate and cannot have dialogical effects, such as in cases iv): "Sorry, what Bob are you talking about?"; "Sorry, what do you mean by 'meat dish'?" (see also the "Hey, wait a minute!” test of Von Fintel 2004). From a communicative point of view, in both cases the hearer can correct what the speaker considers to be shared, bringing to light the "uncommon ground" between the interlocutors (Macagno and Capone 2016; Capone 2013). However, the accusation of the inappropriateness of an assertion in iv) needs to be distinguished from the correction of the presuppositions in cases iii).

The difference between iii) and iv) is at the level of their reasonableness. In iii), the presuppositions are unshared at an epistemic level, as their inappropriateness can be attributed to either to a tentative deceit or a mistake. In iv), the presuppositions are not only unshared; they cannot be considered as possibly part of the hearer's common ground. They are unreasonable. In order to account for this difference, we need to take into account the grounds of taking a proposition for granted, namely the presumptions characterizing the speaker's activity (Strawson 1950:332). 
Presupposing a proposition has a specific effect, namely leading the interlocutor to holding that the speaker has some reason for taking it for granted. By presupposing, the speaker indicates that s/he has a reason for presuming that the hearer either has accepted it already, or can accept it. Therefore, the speaker needs to have some reasons for concluding that the presupposed proposition (presented as a possible previous commitment of the hearer) does not openly conflict with the hearer's commitments (Atlas and Levinson 1981:40-41), or at least the ones that heearer holds more steadily. Thus, a proposition can be presupposed because it has been already accepted by him (it is part of the context), or (as a weaker criterion) the hearer is not known to be committed to conflicting propositions (Soames 1982:486).

The reasonableness of presuppositions can explain also the differences between i) and ii), and ii) and iii). Let us consider i). In case a), in a pub the intention of buying a drink needs to be presumed, as it is part of an implied contract. In b), in a restaurant the intention of having a drink and not only water is commonly presumed, as part of social habits. In c), the party the speaker is referring to can be presumed as it belongs to the propositions shared by the group of friends. The strength of the reasons for presupposing has a direct effect on the rejection of a presupposition. The rejection of the presupposition of a) would require arguments (for not knowing the rule or not intending to comply with it). In c), the lack of knowledge of the presupposed content can be criticized, and the rejection thereof would require evidence.

The scenario in ii) is different. The hearer is entitled not to be committed to the presupposed content and waits (or can wait) for further information. The hearer can decide to be committed under the condition of being provided with the needed information or arguments at a later stage of the dialogue or discourse. In iii), the presuppositions are not acceptable for epistemic reasons. The speaker has a reason for presuming that the hearer can accept the presupposed content, because either $\mathrm{s} /$ he can be committed to it (in b), or can be at least not be committed to its contrary (in a). The reasons for presupposing, however, lack in iv), in which the presupposed contents cannot be presumed to be part of the hearer's commitment store. Here, the speaker's presuppositions are grounded on unreasonable and unacceptable presumptions.

To conclude this section, we notice that the idea of commitment can lead to an interpretation of presupposition not in terms of "common knowledge," but of expectations, namely argumentative reasoning. The criteria of non-controversiality and plausibility of acceptance as conditions for presupposing shift the focus from an analysis of what is known to what can be presumed to be accepted. A presupposition thus becomes the outcome of a reasoning process, which can be reasonable or not, and can yield different interpretative conclusions. 


\section{Presupposition and presumptive reasoning}

The sections above lead to the idea that presuppositions can be analyzed in terms of presumptions. This account has two crucial implications. First, presuppositions can be investigated considering their reasoning dimension. Second, presuppositions unshared or unacceptable by the hearer sometimes can be the trigger of a more complex interpretive reasoning. On this view, the "unreasonableness" of a presupposition can indicate to the hearer the need of a non-defaultive interpretation (Giora et al. 2015, 2017).

\subsection{Presumptive reasoning}

As mentioned above, the decision to take some information as already accepted by the hearer needs to be grounded on reasons. This aspect distinguishes between the correction of a merely false presupposition and the accusation of performing a voluntary inappropriate or infelicitous act. In both cases, the hearer does not accept a commitment the speaker has treated as belonging to the former's "dark-side" commitment store. However, the failure of accepting a presupposition can occur at two distinct levels:

a. Possibility of acceptance: the presupposition can be identified or reconstructed but it cannot be accepted (the hearer is known not to accept the presupposed content);

b. Reasonableness: the presupposition can be identified or reconstructed but the accommodation reasoning cannot be accepted (the hearer cannot be presumed to know or accept the presupposed content).

In particular, the reasonableness criterion is based on the notion of presumption, which bridges the gap between the speaker's and hearer's mind from an epistemic and argumentative perspective (Macagno and Walton 2014:chap. 5; Macagno 2015). This idea is the development of Strawson's presumption of knowledge(Strawson 1971:58-59; Kempson 1975:166-167) and the principle of Relativity developed by Atlas and Levinson (Atlas and Levinson 1981:40):

1. Do not say what you believe to be highly noncontroversial-that is, to be entailed by the presumptions of the common ground.

2. Take what you hear to be lowly noncontroversial-that is, consistent with the presumptions of the common ground.

A proposition can be presupposed not only when it is explicitly accepted, but also when it can be presumed to be part of the hearer's commitment store 
(see Simons 2013), based on a reasoning that can be represented by means of a defeasible scheme of reasoning (Walton et al. 2008). This type of reasoning is called presumptive reasoning, a type of inference that can be described as follows (Rescher 2006:33):

Premise 1: $\quad P$ (the proposition representing the presumption) obtains whenever the condition $C$ obtains unless and until the standard default proviso $D$ (to the effect that countervailing evidence is at hand) obtains (Rule).

Premise 2: $\quad$ Condition $C$ obtains (Fact).

Premise 3: $\quad$ Proviso $D$ does not obtain (Exception).

Conclusion: $P$ obtains.

The reasoning is grounded on a rational defeasible principle, which can be based on recurrences, statistics, causal laws, linguistic rules, etc. This principle is only presumptive, namely it is generally the case, unless some circumstances obtain. The defeasible nature of presumptions can explain the difference between the cases iii) and iv) in the section above. In iii), the presupposed propositions can be presumed to be accepted or acceptable (mothers usually do not know specific information about their children's social life), but they are not because a default proviso obtains. In iv), the presumptions of the speaker are defeated by the evidence accessible to the speaker (and in conflict with the shared presumptions), and for this reason they are unacceptable generalizations.

This type of reasoning can be used to describe the nature of the presupposed propositions, namely the possible reasonable ground on which they are based. A proposition can be thus presumed to be already accepted by the hearer based on different types of presumptive rules concerning what an interlocutor can be expected to accept (or in a stronger sense, to know) (Rescher 2006:6). Such rules can be classified according to their subject matter, and can include the following categories:

$\mathrm{P}_{0}$. Pragmatic presumptions (relationships between a speech act and the speaker's intentions).

$P_{1}$. Linguistic presumptions (commonly accepted meaning of lexical items; definitions: rules of language...).

$\mathrm{P}_{2}$. Encyclopedic presumptions (information that considered to be shared because it concerns individuals, facts, events, and descriptions of the world as socially conceived).

$\mathrm{P}_{3}$. Behavioral presumptions (habits).

$\mathrm{P}_{4}$. Value presumptions (expectations about preferences). 
These categories can be more or less specific, or rather, include defeasible generalizations more or less related to the participant to the concerned dialogue. The presumptions can be about the interlocutor as the present individual, or as a member of a more or less generic culture (Clark 1996:113-115; Kecskes 2013:4; Kecskes and Zhang 2013). Thus, the types of presumption may have a different presumptive nature (Specific or Generic). In the first case, the presumptions can concern the following:

$\mathrm{P}_{0} \mathrm{~S}$. How my interlocutor $(H)$ usually acts linguistically (usually $H$ thanks the interlocutor very gently when offended);

$\mathrm{P}_{1} \mathrm{~S}$. How $H$ usually uses certain linguistic items ( $H$ usually uses the term "drunk" to mean "tipsy");

$\mathrm{P}_{2} \mathrm{~S}$. What kind of information $H$ usually knows ( $H$ never reads newspapers);

$\mathrm{P}_{3} \mathrm{~S}$. How $H$ behaves ( $H$ never writes recommendation letters);

$\mathrm{P}_{4} \mathrm{~S}$. How $H$ orders his preferences ( $H$ prefers sincerity to politeness).

The same categories of presumptions can be used to predict the dark-side commitments of an interlocutor considered as a member of a specific culture (Kecskes 2015; Macagno and Bigi 2017). The presumptions are thus more generic, and concern how (based on the observation of the behavior of the concerned group) an individual belonging to a certain cultural group usually behaves, what s/he usually holds as true, etc. These latter presumptions are more defeasible than the more specific ones, and thus can be defeated by the former and are more likely to be subject to default when more contextual information concerning the hearer is provided. The mechanism of presumptive reasoning, based on the ordering of presumptions, can explain and predict both the functioning of interpretation in case of shared presuppositions, and the various phenomena and effects resulting from unshared presuppositions.

\subsection{Conflicts of presumptions and non-defaultive interpretation}

The analysis of presuppositions as the conclusion of a pattern of presumptive reasoning that is subject to default depending on the type and nature of the presumption allows investigating the rejection of a presupposition and the process of accommodation in terms of reasonableness. As Strawson pointed out, the speaker who presupposes a proposition is in a dialectical position different from the one who has to choose whether to accept it or refuse it. A presupposition implicitly conveys the presumption that the speaker has reasons 
for taking the presupposed information as already accepted, placing "hearers who want to object to them in an awkward rhetorical position" (Potts, 2015, p. 174). An unacceptable (or rejected) presupposition amounts to a mistake in reasoning, or even a form of unreasonableness resulting from contradicting premises.

For example, we analyze the presumption carried by the aforementioned sentence "The king of France is wise" uttered in the present days:

Premise 1: $\quad P$ ( $H$ accepts that there is a king of France/that France is a monarchy) obtains whenever the condition $C$ ( $H$ belongs to the community of people informed on the political situation of important countries) obtains unless and until the standard default proviso $D$ ( $H$ is a child: $H$ is completely disinterested in what happens in the world, etc.) obtains (Rule).

Premise 2: $\quad$ Condition $C$ obtains (Fact).

Premise 3: $\quad$ Proviso $D$ does not obtain (Exception).

Conclusion: $P$ ( $H$ accepts that there is a king of France) obtains.

This type of reasoning represents the speaker's presumptive reasoning, which can be evaluated by comparing the presumptive rule with the presumptions available in the given culture. The speaker's generic encyclopedic presumption ( $\mathrm{P}_{2} \mathrm{G}$. France is usually known to be a monarchy) conflicts with evidence (France is a republic), backing another generic and stronger encyclopedic presumption $\left(\mathrm{P}_{2} \mathrm{G}\right.$. France is known to be a republic).

This conflict of presumptions can be explained by the hearer in different ways. $\mathrm{S} /$ he can explain the mistaken presumption as caused by the fact that the speaker is disoriented in time (namely assuming a default condition $D$ ). Otherwise, s/he can assess the linguistic presumption that "king" refers to "a man who holds by life tenure, and usually by hereditary right, the chief authority over a country and people," and assume that the speaker is speaking metaphorically to mean "a politician who is concentrating too much power" (default of a linguistic presumption) (Ducrot 1966:42). This type of non-presumptive interpretation can be explained through the assessment of the presumptions available to the hearer and the evidence available:

1 For an actual interpretive debate over the "king of France" see the discussion between the former president of France, Sarkozy, and a journalist, Mr Joffrin, accusing the former of having turned France into a monarchy. Sarkozy replied that as far as he knows, his father did not enthrone him as the king. See Troisième conférence de presse en quatre ans pour Sarkozy, Le Monde.fr 24 January 2011, retrieved from https://is.gd/aq8oDR (accessed on 23 March 2017). 
1. $\mathrm{P}_{2} \mathrm{G}$. France is usually known to be a monarchy (presumed by the speaker).

2. $\mathrm{P}_{2} \mathrm{G}$. France is known to be a republic.

3. Evidence: France is a republic.

Conflict of presumptions 1 and 2: need of explanation. Assessing available presumptions:

4. $\mathrm{P}_{0} \mathrm{~S}$. The speaker is not joking (he aims at informing the hearer).

5. $\mathrm{P}_{2} \mathrm{~S}$. The speaker is presumably aware of the most important information concerning the world (Evidence: $\mathrm{s} /$ he is not in a daze nor confused)

6. $\mathrm{P}_{1} \mathrm{G}$. A "king" usually means "a man holding $[. .$.$] the chief authority over a$ country and people."

In this case, the hearer has to weigh the various available presumptions and exclude the most defeasible one considering the available evidence. While the encyclopedic and pragmatic presumptions are backed by evidence and hardly likely to be defeated in the given context, the linguistic presumption at point 6 is only a generic presumption, which can be subject to default, leading to a metaphorical interpretation.

The same mechanism of weighting and assessing the available presumptions can explain other types of non-defaultive interpretation. For example, we consider the following sentence (Macagno and Capone 2016):

$<$ On a sign posted in a restaurant $>$ Thank you for not smoking.

The presupposed content triggered by "thank you for" cannot be taken for granted by the speaker, as it cannot be presumed to be shared, accepted, or acceptable by the hearer. The conflict of presumptions can be represented as follows:

1. $\mathrm{P}_{3} \mathrm{G}$. People entering a restaurant usually have decided not to smoke in the restaurant (presumed by the speaker).

2. $\mathrm{P}_{3} \mathrm{G}$. People usually smoke in restaurants.

3. Evidence: In absence of regulations to the contrary, people usually smoke in public places.

Conflict of presumptions 1 and 2: need of explanation. Assessing available presumptions:

4. $P_{0} G$. "Thank you" is usually used to thank the interlocutor for a curtesy, service, or favor.

5. Evidence: The hearer has not done any courtesy, service, or favor.

6. $\mathrm{P}_{2} \mathrm{G}$. The speaker is presumably aware of the most important information concerning the world. 
7. $P_{1} G$. Whoever writes signs in restaurants usually uses words with their ordinary (most accessible) meaning.

Among the available presumptions, the pragmatic one (at 4) is the weakest one, as it conflicts with the available evidence and other presumptions (at 5 and 6). For this reason, the purpose of the utterance needs to be explained in a nonpresumptive fashion. Since it introduces a commitment to a specific action (the hearer becomes committed to "not smoking") without the hearer's previous acceptance, the communicative purpose is to impose a commitment (namely, ordering the hearer not to smoke). The communicative effect is different from an explicit order, as the result of not accepting the commitment is not a breach of a command but a rejection of an expression of gratitude.

The examples of acceptable and unacceptable presuppositions explained in this section show how presuppositions can be analyzed considering the reasons underlying their status of "previously accepted" propositions. They are treated by the speaker as the hearer's dark-side commitments. For this reason, they carry a specific presumption that the speaker has reasons to draw this conclusion. This dialectical effect can be analyzed as a pattern of reasoning grounded on presumptive rules, which in turn can be examined by taking into account their type and their nature. The presumptive reasoning on which a presupposition is based can be thus brought to light and its reasonableness assessed, pointing out the presumptions used and their possible defaults (Geurts 1999:32-33).

\section{Conclusion}

This paper advanced a dialectical approach to presupposition rooted in the concept of commitment. In particular, in this approach the "logical" dimension of presupposition is used to explain its dialogical behavior, which is accounted for in terms of commitment, a dialectical notion weaker than truth and belief (or knowledge).

The ancient and medieval dialectical works provided two distinct insights for the analysis of presupposition. First, from the point of view of the assessment of a sentence-token (excluding incomplete or spurious sentences), a false presupposition results in the falsity of the whole sentence. In this fashion, it is possible to check the consistency of the interlocutors' commitment set, or the negation of presuppositions in specific assertive speech acts. Second, from a dialectical point of view, presuppositions are also characterized by a pragmatic 
dimension, namely the alteration of the dialectical order of acceptance. A presupposition is a proposition that the speaker can consider as already included in the hearer's commitment store, so s/he can act as it were part of the hearer's commitments without securing its acceptance. A false presupposition is thus a disruption of the order of acceptance, and can be denied either at a logical level (assessment level - " $p$ is false") or at a pragmatic level (denying the previous acceptance of the presupposition - "I have never accepted $p$ ”).

In this paper, the implications of a dialectical approach have been developed, focusing on the reasoning mechanism characterizing both the speaker's presupposition and the hearer's acceptance or reconstruction and interpretation thereof. The view proposed is grounded on the premises that a presupposition is a proposition previously accepted by the hearer, and that such an acceptance cannot be known, but only presumed. Therefore, the speaker needs to have reasons for presupposing, namely for concluding that the hearer has already accepted a presupposed proposition. S/he can access the interlocutor's acceptance of a proposition only through presumptive reasoning, aimed at drawing conclusions from premises describing the ordinary or normal expectations.

On this perspective, presuppositions are investigated in terms of presumptions, defeasible generalizations that can be weighted and assessed in the interpretative process. Presumptions can be classified according to their content and nature in types having different levels of generalizations (namely concerning a broader or narrower group or only the interlocutor), and depending on their specificity, they can be more or less subject to default. A false (or rather unaccepted) presupposition can be thus represented as the result of an underlying defaulted or even unsound pattern of presumptive reasoning.

At the interpretative level, unaccepted presuppositions are regarded as a conflict of presumptions that can be explained by comparing the available presumptions and evidence. On this view, when confronted with an unaccepted or unacceptable presupposition, the hearer can assess the underlying reasoning and provide the best explanation of the apparent flawed implicit reasoning. In this fashion, s/he can detect the default of the weakest presumption, and replace it with a stronger one, backed by the available evidence. This "operational" approach to presupposition in terms of presumptive reasoning can provide a bridge between pragmatics and the modern developments of ancient dialectics, including the studies in the fields of argumentation, logic, and cognitive psychology. More importantly, it can account for the effects and problems of intercultural and intracultural differences (Macagno and Walton 2014:chap. 5; Macagno and Capone 2016; Macagno 2012b; Macagno and Bigi 2017) and the possible different interpretations that are triggered by unacceptable presuppositions. 


\section{References}

Abaelardus, Petrus. 1970. Dialectica. Lambertus Marie De Rijk (Ed.), Assen: Van Gorcum.

Aquinas, St Thomas. 1961. Commentary on the metaphysics of Aristotle. John Rowan (Ed.), Chicago: Henry Regnery Co.

Aquinas, St Thomas. 1962. Expositio libri Peryermeneias. Oeste, Jea. Milwaukee: Marquette University Press.

Aquinas, St Thomas. 1990. Summa Theologiae: Volume 11, Man: 1a. 75-83. Timothy Suttor (Ed.), Cambridge: Cambridge University Press.

Aquinas, St Thomas. 2006. Summa Theologiae: Volume 32, Consequences of Faith: 2a2ae. 8-16. Thomas Gilby (Ed.), Cambridge: Cambridge University Press.

Asher, Nicholas \& Alex Lascarides. 1998. The semantics and pragmatics of presupposition. Journal of Semantics 15(3). 239-300. doi:10.1093/jos/15.3.239.

Ashworth, Jennifer. 1973. Existential Assumptions in Late Medieval Logic. American Philosophical Quarterl 10(2). 141-147.

Atlas, Jay David. 1991. Topic/comment, presupposition, logical form and focus stress implicatures: The case of focal particles only and also. Journal of Semantics 8(1-2). 127-147.

Atlas, Jay David. 2004. Descriptions, linguistic topic/ comment,and negative existentials: A case study in the application of linguistic theory to problems in the philosophy of language. In Marga Reimer \& Anne Bezuidenhout (eds.), Descriptions and beyond, 342-360. Oxford: Oxford University Press.

Atlas, Jay David. 2005. Logic, meaning, and conversation. Oxford: Oxford University Press. doi: 10.1093/acprof:oso/9780195133004.001.0001. http://www.oxfordscholarship.com/view/ 10.1093/acprof:oso/9780195133004.001.0001/acprof-9780195133004

Atlas, Jay David. 2008. Presupposition. In Laurence Horn \& Gregory Ward (eds.), The Handbook of pragmatics, 29-52. Oxford: Blackwell Publishing Ltd. doi:10.1002/9780470756959.ch2.

Atlas, Jay David \& Stephen Levinson. 1981. It-clefts, informativeness and logical form: Radical pragmatics (revised standard version). In Peter Cole (ed.), Radical pragmatics, 1-62. New York: Academic Press.

Bach, Kent. 1999. The myth of conventional implicature. Linguistics and Philosophy 22. 237-366.

Beaver, David. 2010. Have you noticed that your belly button lint colour is related to the colour of your clothing. In Rainer Bäuerle, Uwe Reyle \& Thomas Zimmerman (eds.), Presuppositions and Discourse: Essays Offered to Hans Kamp, 65-99. Oxford: Elsevier.

Beyssade, Claire \& Jean-Marie Marandin. 2006. The speech act assignment problem revisited: Disentangling speaker's commitment from speaker's call on addressee. In Olivier Bonami \& Patricia Cabredo Hofherr (eds.), Empirical issues in syntax and semantics, 37-68. vol. 6. Paris: Presses Universitaires de Paris Sorbonne.

Beyssade, Claire \& Jean-Marie Marandin. 2009. Commitment: Une attitude dialogique. Langue française 162(2). Armand Colin/Dunod. 89. doi:10.3917/If.162.0089. (30 September, 2016). http://www.cairn.info/revue-langue-francaise-2009-2-page-89.htm

Brennan, Susan \& Herbert Clark. 1996. Conceptual pacts and lexical choice in conversation. Journal of Experimental Psychology: Learning, Memory, and Cognition 22(6). 1482-1493.

Capone, Alessandro. 2013. The pragmatics of pronominal clitics and propositional attitudes. Intercultural Pragmatics 10(3). 459-485. doi:10.1515/ip-2013-0020. 
Capone, Alessandro. 2017. Presuppositions as conversational phenomena. Lingua 198. 22-37. doi:10.1016/j.lingua.2017.06.014.

Clark, Herbert. 1996. Using Language. Cambridge: Cambridge University Press.

Clark, Herbert \& Susan Brennan. 1991. Grounding in communication. In Lauren Resnick, John Levine \& Stephanie Teasley (eds.), Perspectives on socially shared cognition, 127-149. Washington: American Psychological Association.

Ducrot, Oswald. 1966. "Le roi de France est sage". Implication logique et Présupposition linguistique. Etudes de linguistique appliquée 4. 39-47.

Ducrot, Oswald. 1968. Le structuralisme en linguistique. In Oswald Ducrot \& Tzvetan Todorov (eds.), Qu'est-ce que le structuralisme?, 13-96. Paris: Seuil.

Ducrot, Oswald. 1984. Le dire et le dit. Paris: Minuit.

Fintel, Kai von. 2008. What is Presupposition Accommodation, Again?. Philosophical Perspectives 22(1). 137-170. doi:10.1111/j.1520-8583.2008.00144.x.

Fintel, Kai Von. 2004. Would you believe it? The King of France is back! (Presuppositions and truth-value intuitions). In Marga Reimer \& Anne Bezuidenhout (eds.), Descriptions and Beyond, 315-341. Oxford: Oxford University Press.

Frege, Gottlob. 1948. Sense and Reference. The Philosophical Review 57(3). 209-230.

Gazdar, Gerald. 1979. A solution to the projection problem. In Oh Choon-Kyu \& David Dinneen (eds.), Syntax and semantics. Vol. 11: Presupposition, 57-89. vol. 1. New York: Academic Press.

Geurts, Bart. 1999. Presuppositions and Pronouns. Oxford: Elsevier.

Geurts, Bart. 2017. Presupposition and givenness. In Yan Huang (ed.), Oxford handbook of pragmatics, 180-198. Oxford: Oxford University Press.

Ginzburg, Jonathan. 1994. An Update Semantics for Dialogue. In Harry Bunt, Reinhard Muskens \& Gerrit Rentier (eds.), Proceedings of the 1st International Workshop on Computational Semantics, 111-120. Tilburg: Institute for language technology and artificial intelligence.

Ginzburg, Jonathan. 1996. Dynamics and the semantics of dialogue. In Jerry Seligman \& Dag Westerstahl (eds.), Logic, language and computation 1, 221-237. Stanford, CA: CSLI publications.

Giora, Rachel, Ari Drucker, Ofer Fein \& Itamar Mendelson. 2015. Default Sarcastic Interpretations: On the Priority of Nonsalient Interpretations. Discourse Processes 52(3). 173-200. doi:10.1080/0163853X.2014.954951. (24 November, 2016).

Giora, Rachel, Shir Givoni, Vered Heruti \& Ofer Fein. 2017. The Role of Defaultness in Affecting Pleasure: The Optimal Innovation Hypothesis Revisited. Metaphor and Symbol 32(1). 1-18. doi:10.1080/10926488.2017.1272934.

Gundel, Jeanette K. \& Thorstein Fretheim. 2004. Topic and Focus. In Laurence Horn \& Gregory Ward (Ed.), The Handbook of Pragmatics(1974), 175-196. London: Blackwell. doi:10.1002/ 9780470756959.ch8.

Hamblin, Charles Leonard. 1970. Fallacies. London: Methuen.

Hispanus, Petrus. 1990. Peter of Spain: Language in Dispute. An English translation of Peter of Spain's' Tractatus' called afterwards Summulae Logicales, based on the critical edition by LM de Rijk. Francis Dinneen (Ed.), Amsterdam: John Benjamins Publishing.

Hispanus, Petrus. 1992. Syncategoreumata. Lambertus Maria Rijk \& Joke Spruyt (Ed.), Brill: Leiden.

Hobbs, Jerry R. 1979. Coherence and coreference. Cognitive Science 3. 67-90. doi:10.1207/s155167 09cog0301_4.

Horn, Laurence. 1996. Presupposition and implicature. In Shalom Lappin (ed.), The Handbook of Contemporary Semantic Theory, 299-319. Oxford: Blackwell. 
Horn, Laurence. 2011. ONLY XL: The assertoric asymmetry of exponibles. In Ed Cormany, Satoshi Ito \& David Lutz (eds.), Proceedings of Semantics and Linguistic Theory (SALT, 198-222. Ithaca: CLC Publications.

Huang, Yan. 2014. Pragmatics. Oxford: Oxford University Press.

Kecskes, Istvan. 2013. Intercultural pragmatics. Oxford: Oxford University Press.

Kecskes, Istvan. 2015. Intracultural communication and intercultural communication: Are they different?. International Review of Pragmatics 7. 171-194. doi:10.1163/1877310900702002.

Kecskes, Istvan \& Fenghui Zhang. 2009. Activating, seeking, and creating common ground: A sociocognitive approach. Pragmatics \& Cognition 17(2). 331-355. doi:10.1075/pc.17.2.06kec.

Kecskes, Istvan \& Fenghui Zhang. 2013. On the Dynamic Relations Between Common Ground and Presupposition. In Alessandro Capone, Franco Lo Piparo \& Marco Carapezza (eds.), Perspectives on Linguistic Pragmatics, Perspectives in Pragmatics, 375-395. Philosophy \& Psychology 2. Cham: Springer.doi:10.1007/978-3-319-01014-4_15.

Kempson, Ruth. 1975. Presupposition and the Delimitation of Semantics. Cambridge: Cambridge University Press.

Kienpointner, Manfred. 1992. Alltagslogik: Struktur und Funktion von Argumentationsmustern. Stuttgart, Germany: Fromman-Holzboog.

Kienpointner, Manfred. 2001. Modern revivals of Aristotle's and Cicero's Topics: Toulmin, Perelman, Anscombre/Ducrot. Journal of Latin Linguistics 7(1). 17-34.

Levinson, Stephen. 2000. Presumptive meanings: The theory of generalized conversational implicature. Cambridge, Mass.: MIT Press.

Lewis, David. 1979. Scorekeeping in a language game. Journal of Philosophical Logic 8(1). 339-359. doi:10.1007/BF00258436.

Libera, Alain De. 2011. Dénomination extrinsèque et « changement cambridgien ». Éléments pour une archéologie médiévale de la subjectivité. In Kent Emery, Russell Friedman \& Andreas Speer (eds.), Philosophy and Theology in the Long Middle Ages, 451-470. Leiden: Brill.

Macagno, Fabrizio. 2012a. Reconstructing and Assessing the Conditions of Meaningfulness: An Argumentative Approach to Presupposition. In Henrique Ribeiro (ed.), Inside Arguments: Logic and the Study of Argumentation, 247-268. Newcastle upon Tyne: Cambridge Scholars Publishing.

Macagno, Fabrizio. 2012b. Presumptive reasoning in interpretation. Implicatures and conflicts of presumptions. Argumentation 26(2). Springer Netherlands. 233-265. doi:10.1007/ s10503-011-9232-9.

Macagno, Fabrizio. 2015. Presupposition as argumentative reasoning. In Alessandro Capone \& Jacob Mey (eds.), Interdisciplinary Studies in Pragmatics, Culture and Society, 465-487. Cham: Springer. doi:10.1007/978-3-319-12616-6_18.

Macagno, Fabrizio \& Sarah Bigi. 2017. Understanding misunderstandings. Presuppositions and presumptions in doctor-patient chronic care consultations. Intercultural Pragmatics 14(1). 49-75. doi:10.1515/ip-2017-0003.

Macagno, Fabrizio \& Alessandro Capone. 2016. Uncommon ground. Intercultural Pragmatics 13(2). 151-180. doi:10.1515/ip-2016-0007.

Macagno, Fabrizio \& Douglas Walton. 2014. Emotive Language in Argumentation. New York: Cambridge University Press. doi:10.1017/СB09781139565776.

MacFarlane, John. 2015. Abelard's Argument for Formality. In Laurent Cesalli, Alain De Libera \& Frederic Goubier (eds.), Formal Approaches and Natural Languages in the Middle Ages, 41-57. Turnhout: Brepols. 
Mackenzie, Jim \& Phil Staines. 1999. Hamblin's Case for Commitment: A Reply to Johnson. Philosophy \& rhetoric 32(1). 14-39.

Martin, Christopher. 2001. Obligations and liars. In Mikko Yrjönsuuri (ed.), Medieval Formal Logic-Obligations, Insolubles and Consequences, 63-94. Dordrecht: Kluwer Academic Publishers.

Martin, Christopher. 2004. Logic. In Jeffrey Brower \& Kevin Guilfoy (eds.), The Cambridge Companion to Abelard, 158-199. Cambridge: Cambridge University Press.

Martin, Christopher. 2012. Logical consequence. In John Marenbon (ed.), The Oxford Handbook of Medieval Philosophy, 289-311. Oxford: Oxford University Press.

McCabe, Herbert. 1969. Categories. In Anthony Kenny (ed.), Aquinas. A Collection of Critical Essays, 54-92. London: Palgrave Macmillan UK.

Novaes Dutilh, Catarina. 2007. Formalizing Medieval Logical Theories: Suppositio, Consequentiae and Obligationes. Dordrecht: Springer.

Potts, Christopher. 2015. Presupposition and implicature. In Shalom Lappin \& Chris Fox (eds.), The Handbook of Contemporary Semantic Theory, 168-202. Oxford: Wiley-Blackwell.

Rescher, Nicholas. 2006. Presumption and the Practices of Tentative Cognition. Cambridge: Cambridge University Press. doi: 10.1017/CB09780511498848. https://www.cambridge. org/core/product/identifier/9780511498848/type/book

Rhonheimer, Martin. 2000. Natural Law and Practical Reason: A Thomist View of Moral Autonomy. New York: Fordham University Press.

Russell, Bertrand. 1905. On denoting. Mind 14. 479-493.

Schlenker, Philippe. 2008. Be articulate: A pragmatic theory of presupposition projection. Theoretical Linguistics 34(3). 157-212.

Seuren, Pieter. 2005. Eubulides as a 20th-century semanticist. Language Sciences 27(1). 75-95. Seuren, Pieter. 2009. Language in Cognition: Language from Within Volume I: Language from Within. Vol. 1. Oxford: Oxford University Press.

Seuren, Pieter. 2010. The Logic of Language. Language from Within, volume II. Oxford: Oxford University Press, Oxford.

Sherwood, William. 1968. Treatise on Syncategorematic Words. Norman Kretzmann (Ed.), Minneapolis: University of Minnesota Press.

Simons, Mandy. 2003. Presupposition and accommodation: Understanding the Stalnakerian picture. Philosophical Studies 112(3). 251-278.

Simons, Mandy. 2007. Presupposition and cooperation. Carnegie Mellon University. Manuscript. Simons, Mandy. 2013. On the conversational basis of some presuppositions. In Alessandro Capone, Franco Lo Piparo \& Marco Carapezza (eds.), Perspectives on Linguistic Pragmatics, Perspectives in Pragmatics, Philosophy \& Psychology 2, 329-348. Cham: Springer.

Soames, Scott. 1982. How Presuppositions Are Inherited: A Solution to the Projection Problem. Linguistic Inquiry 13(3). 483-545.

Stalnaker, Robert. 1973. Presuppositions. Journal of philosophical logic 2(4). 447-457. doi:10.1007/bf00262951.

Stalnaker, Robert. 1974. Pragmatic presuppositions. In Milton Munitz \& Peter Unger (eds.), Semantics and Philosophy, 197-214. New York: Press. doi:10.1093/0198237073.003.0003.

Stalnaker, Robert. 1984. Inquiry. Cambridge, Mass.: MIT Press.

Stalnaker, Robert. 2008. A Response to Abbott on Presupposition and Common Ground. Linguistics and Philosophy 31(5). 539-544.

Strawson, Peter. 1950. On referring. Mind 59(235). 320-344. 
Strawson, Peter. 1964. Identifying reference and truth-values. Theoria 30(2). 96-118. Wiley Online Library.

Strawson, Peter. 1971. Identifying Reference and Truth-Values. In Peter Strawson (ed.), Logico-Linguistic Papers, 75-95. London: Methuen.

Thomason, Richmond. 1990. Accommodation, meaning, and implicature: Interdisciplinary foundations for pragmatics. In Philip Cohen, Jerry Morgan \& Martha Pollack (eds.), Intentions in communication, 325-364. Cambridge: MIT Press.

Toulmin, Stephen. 1958. The uses of argument. Cambridge: Cambridge University Press.

Uckelman, Sara L. 2013. Medieval Disputationes de obligationibus as Formal Dialogue Systems. Argumentation 27(2). 143-166. doi:10.1007/s10503-012-9266-7.

Walton, Douglas. 2006. Fundamentals of critical argumentation. New York: Cambridge University Press.

Walton, Douglas \& Erik Krabbe. 1995. Commitment in dialogue. Albany: State University of New York Press.

Walton, Douglas, Christopher Reed \& Fabrizio Macagno. 2008. Argumentation Schemes. New York: Cambridge University Press. doi:10.1017/CB09780511802034.

\section{Bionote}

\section{Fabrizio Macagno}

Fabrizio Macagno (Ph.D. UCSC, Milan, 2008) works as a researcher and invited auxiliary professor at the Universidade Nova de Lisboa. He is author of more than 80 papers on definition, presupposition, argumentation schemes, and dialogue analysis published on major international peer-reviewed journals such as Journal of Pragmatics, Intercultural Pragmatics, Argumentation, and Philosophy and Rhetoric. His most important publications include the books Argumentation Schemes (CUP 2008), Emotive language in argumentation (CUP 2014), and Interpreting straw man argumentation (Springer 2017). 